\title{
A DINÂMICA ATMOSFÉRICA NO VERÃO 2013-2014 NO MUNICÍPIO DE ITIRAPINA/SP E SUA CARACTERIZAÇÃO PLUVIOMÉTRICA UTILIZANDO ANOS PADRÕES
}

\author{
Bruno César dos Santos \\ Universidade de São Paulo, Núcleo de Climatologia \\ Pós-Graduação em Ciências da Engenharia Ambiental São Carlos/SP, Brasil \\ bruno-u'nifal@hotmail.com \\ Rafael Greccho Sanches \\ Universidade de São Paulo, Núcleo de Climatologia \\ Pós-Graduação em Ciências da Engenharia Ambiental São Carlos/SP, Brasil \\ rafagsanches@usp.br \\ Paulo Henrique de Souza \\ Universidade Federal de Alfenas, Instituto de Ciências da Natureza \\ Graduação e Pós-Graduação em Geografia, Alfenas/MG, Brasil \\ phsouza31@hotmail.com
}

\begin{abstract}
RESUMO
O presente estudo analisou os registros pluviométricos da Estação Climatológica do Centro de Recursos Hídricos e Estudos Ambientais da Escola de Engenharia de São Carlos da Universidade de São Paulo (CRHEA EESC/USP) no município de Itirapina/SP com o propósito de identificar no semestre hidrológico do período 2013/2014 o comportamento da precipitação. Aproveitando os dados disponibilizados na série histórica dessa estação, comparou os dados mensais com a média histórica verificando os desvios, aplicando ainda a metodologia de Anos Padrão para verificar o comportamento da precipitação ao longo dos anos e se a situação observada em 20132014 manifestou-se noutros momentos ou se constitui fato isolado. Assim, observou-se que a ação dos sistemas atmosféricos no período estudado, não ocorreu dentro dos parâmetros habituais devido à fraca atuação da ZCAS diante do constante bloqueio atmosférico do Anticiclone do Atlântico Sul (ASAS) sobre o interior do sudeste da América do Sul. O resultado foi uma precipitação acima da média entre os meses de outubro e novembro, e abaixo da média entre os meses de dezembro a março. Também constatou que o total pluviométrico do semestre hidrológico de 2013/2014 apresentou valor abaixo da média, caracterizando a estação do CRHEA/USP como Ano Tendente a Seco.
\end{abstract}

Palavras-chave: Precipitação. ZCAS. Semestre Hidrológico. Atmosfera. Água.

\section{THE ATMOSPHERIC DYNAMICS IN THE SUMMER 2013-2014 IN A MUNICIPALITY OF ITIRAPINA/SP AND ITS PLUVIOMETRIC CHARACTERIZATION USING STANDARDS}

\begin{abstract}
The following study analysed the pluviometric registers from the CRHEA-EESC/USP Wheater Station placed in Itirapina/SP with a purpose to identify in the hydrological semester from the period of 2013/2014 the precipitation behavior according to the months. Based on the data disponibilized of the historical series from this specific station, the research compared the monthly data with the historical average verifying the occurred deviations and applied the Typical Years methodology (Monteiro, 1976) to verify in the available data series the precipitation behavior during the years and if the observed situation from 2013/2014 manifested in different moments or if it constituted an isolated fact. Thus, it was observed that the athmosferical systems action in the studied period didn't occur within the habitual parameters due to the ZCAS (South Atlantic Convergence Zone) insufficient performance before the South Atlantic Anticyclone (ASAS) constant athmosferical block over the South American southeastern hinterland, established over the South Atlantic. The result was a precipitation above average between months of October and November and below average between moths of December and March. It was also determined that the pluviometric total amount from the
\end{abstract}


hydrological semester of 2013/2014 presented a below average value, which characterizes the CRHEA/USP station as a Tending to Dry Year.

Keywords: Precipitation. ZCAS. Hydrological Semester. Atmosphere. Water.

\section{INTRODUÇÃO}

Durante o período primavera-verão de 2013/2014 a região Sudeste do Brasil sofreu com uma significativa diminuição da precipitação em paralelo ao aumento da temperatura, comprometendo seriamente as condições habituais de abastecimento hídrico em razão do binômio representado pelo aumento na demanda de água e diminuição da oferta devido a queda registrada no índice pluviométrico ao longo dos meses de outubro a março que normalmente concentram a maior parte das chuvas anuais para toda a região.

Cumpre salientar que parte significativa das chuvas que ocorrem nesse período do ano resultam da manifestação da ZCAS - Zona de Convergência do Atlântico Sul que alia a umidade transportada desde a região Amazônica através dos jatos de baixos níveis até as regiões centrais do país, aos processos de frontogênese ocasionados pelo avanço das massas polares sob o território nacional (QUADROS et al., 2012).

Obviamente esse padrão atmosférico é definido e estabelecido após a análise dinâmica de suas variáveis climatológicas por uma duração de tempo considerável que permite a identificação dos seus padrões habituais e gênese (NIMER, 1979).

Porém, ao contrário do que costuma acontecer habitualmente nessa época do ano, poucos sistemas frontais conseguiram alcançar o Brasil e a Zona de Convergência do Atlântico Sul que é responsável por parte significativa dos índices pluviométricos registrados no Sudeste (CENTRO DE PREVISÃO DO TEMPO E ESTUDOS CLIMÁTICOS - CPTEC, 2014).

Isso ocasionou diminuição expressiva na precipitação e aumento da temperatura no Sudeste do Brasil, dificultando entre outros, o abastecimento de água e a recuperação dos reservatórios que recompõe seus níveis nesse período do ano, após a estiagem que ocorre de abril a setembro. Em decorrência dessa alteração nos padrões atmosféricos, os ecossistemas da região ficaram prejudicados, exemplificando como a ocorrência de conjunturas climáticas excepcionais podem impactar através das alterações significativas que promovem.

Segundo Marengo et al (2015) entendem, uma seca dessa dimensão que afeta os níveis dos mananciais e ocasiona um grave problema social, é, precisamente um tipo de fenômeno climático excepcional que apesar de inesperado e significativo, não deixa de expor a falta de eficiência no gerenciamento dos recursos hídricos por parte do poder público.

Em face disto, planejar ações para lidar com esses cenários que destacam a relevância das questões hídricas, inserindo nesse contexto a geração de energia, a indústria e o turismo, entre outras atividades socioeconômicas, torna-se imperativo (CARMO et al, 2014).

Atentando para isto, o presente estudo foi desenvolvido no município de Itirapina/SP, situado na região Centro-Leste do estado de São Paulo que possui como configuração atmosférica se classifica como Tropical de altitude. Nimer (1972) identifica essa porção do território paulista com uma estação seca acompanhada por temperaturas menos elevadas (outono-inverno) e outra chuvosa com temperaturas mais elevadas (primavera-verão).

A fim de identificar as principais alterações registradas junto à habitualidade climática da área de estudo, a presente pesquisa analisou o comportamento das precipitações que se concentram nos seis meses mais chuvosos (outubro a março, denominado 'semestre hidrológico'), por meio da consulta aos dados disponibilizados pela estação climatológica do CRHEA-USP (Centro de Recursos Hídricos e Estudos Ambientais) da EESC/USP (Escola de Engenharia de São Carlos da Universidade de São Paulo).

Para tanto, efetuaram-se comparações entre os valores anotados no semestre hidrológico compreendido entre outubro de 2013 e março de 2014 frente a série histórica de trinta e quatro anos imediatos a esse período, por meio da metodologia de Anos-Padrão e da análise do desvio 
da média que classifica os períodos em cinco modalidades - Normal, Chuvoso, Tendente a Chuvoso, Seco, e, Tendente a Seco. Caracterizou-se ainda o referido semestre hidrológico segundo tal classificação, destacando, toda a dinâmica dos sistemas atmosféricos atuantes e conjuntura estabelecida nos padrões climáticos que resultaram nos acumulados pluviométricos registrados.

\section{MATERIAIS E MÉTODO}

No presente estudo foi utilizado tratamento quantitativo dos dados diários de chuvas tendo por base os índices contidos em uma série histórica de trinta e quatro anos (1980-2014), imediatos ao semestre hidrológico 2013-2014 que se encontram armazenados na estação climatológica localizada nas coordenadas 22'10'12" (S) e 47053'55" (W), numa altitude de 737m, no CRHEA da EESC/USP no município de Itirapina/SP (Figura 1). Esses dados descrevem a conjuntura do período que se manifestou ano a ano caracterizando uma habitualidade e revelando situações específicas ainda que próximas ao padrão estabelecido pela média.

Figura 1: Localização da Área de Estudo e da Estação Climatológica do CRHEA/USP.

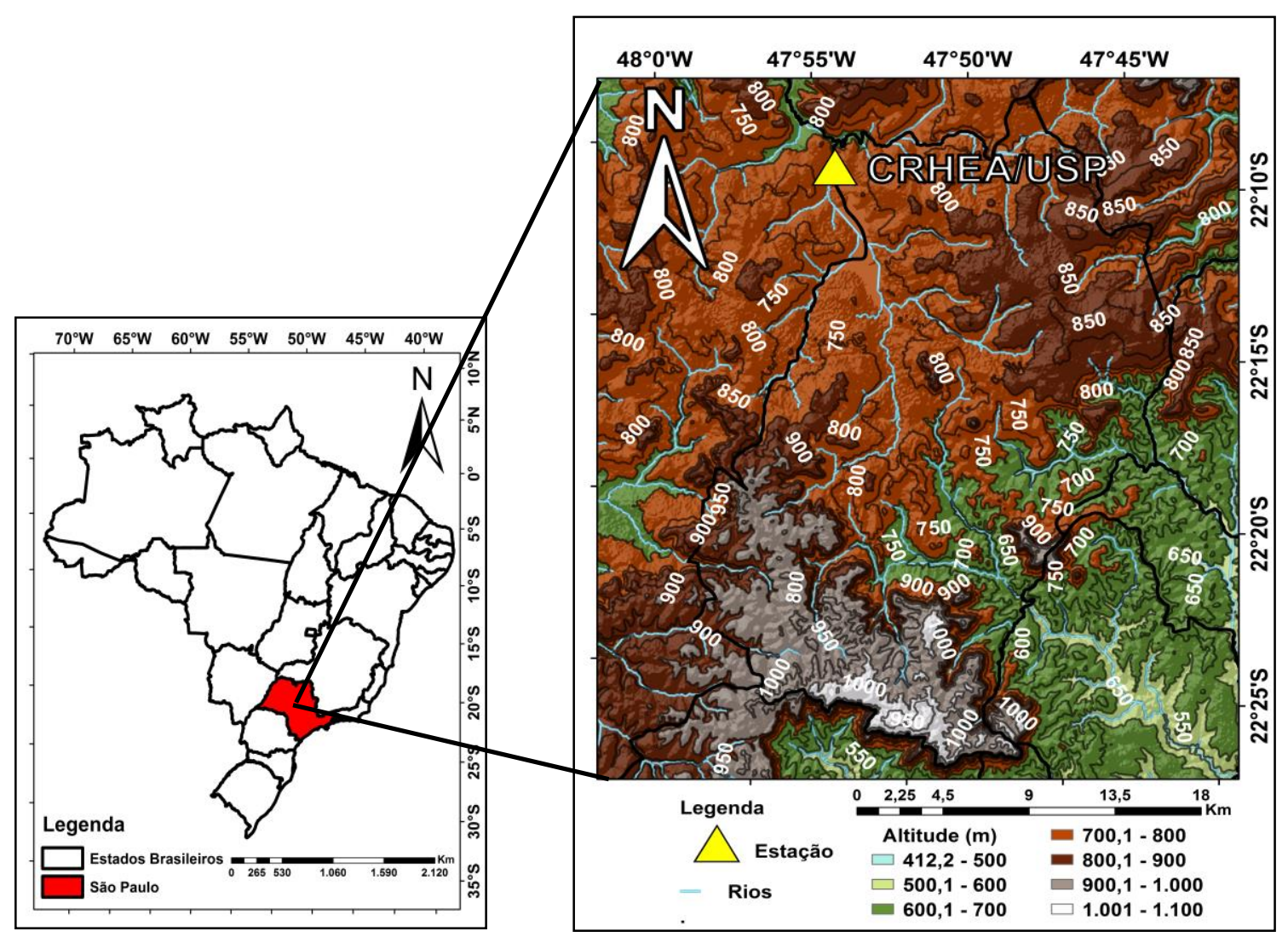

Elaborado pelos autores/2018.

A área de estudo tem seu território inserido no espaço dinâmico de atuação da Zona de Convergência do Atlântico Sul e das massas equatoriais (massa Equatorial continental), tropicais (massa Tropical atlântica e massa Tropical continental) e polar (massa Polar atlântica) que incidem sobre a porção Centro-Sul do Brasil, enquadrando-se pelo relevo e latitude na condição de região com clima tropical de altitude caracterizado por inverno seco e verão chuvoso (MONTEIRO, 1973).

Diante disto os índices pluviométricos na região de Itirapina/SP estão bem definidos pela sazonalidade com semestre seco (outono-inverno) limitado pelos meses de abril a setembro, e, semestre chuvoso 
(primavera-verão) estabelecido entre outubro e março. No presente estudo, atribui-se a este último a denominação de ano hidrológico (Gráfico 1).

Além dos dados de chuva, foram necessárias ao estudo as informações concernentes à circulação atmosférica no período de outubro de 2013 a março de 2014. Neste caso, recorreu-se ao conteúdo fornecido pelas cartas sinóticas que são lançadas diariamente pela Divisão de Previsão Ambiental do Centro de Hidrografia da Marinha do Brasil e pelo INPE (00TMG, 06TMG, 12TMG e 18TMG). Através delas sãos identificadas as movimentações atmosféricas ocorridas ao longo do período, verificando a ação das massas de ar e dos sistemas de divergência ou convergência de ventos.

Gráfico 1: Precipitação (mm) média mensal do período 1980-2014 para região de Itirapina/SP segundo dados colhidos pela estação do CRHEA da EESC/USP.

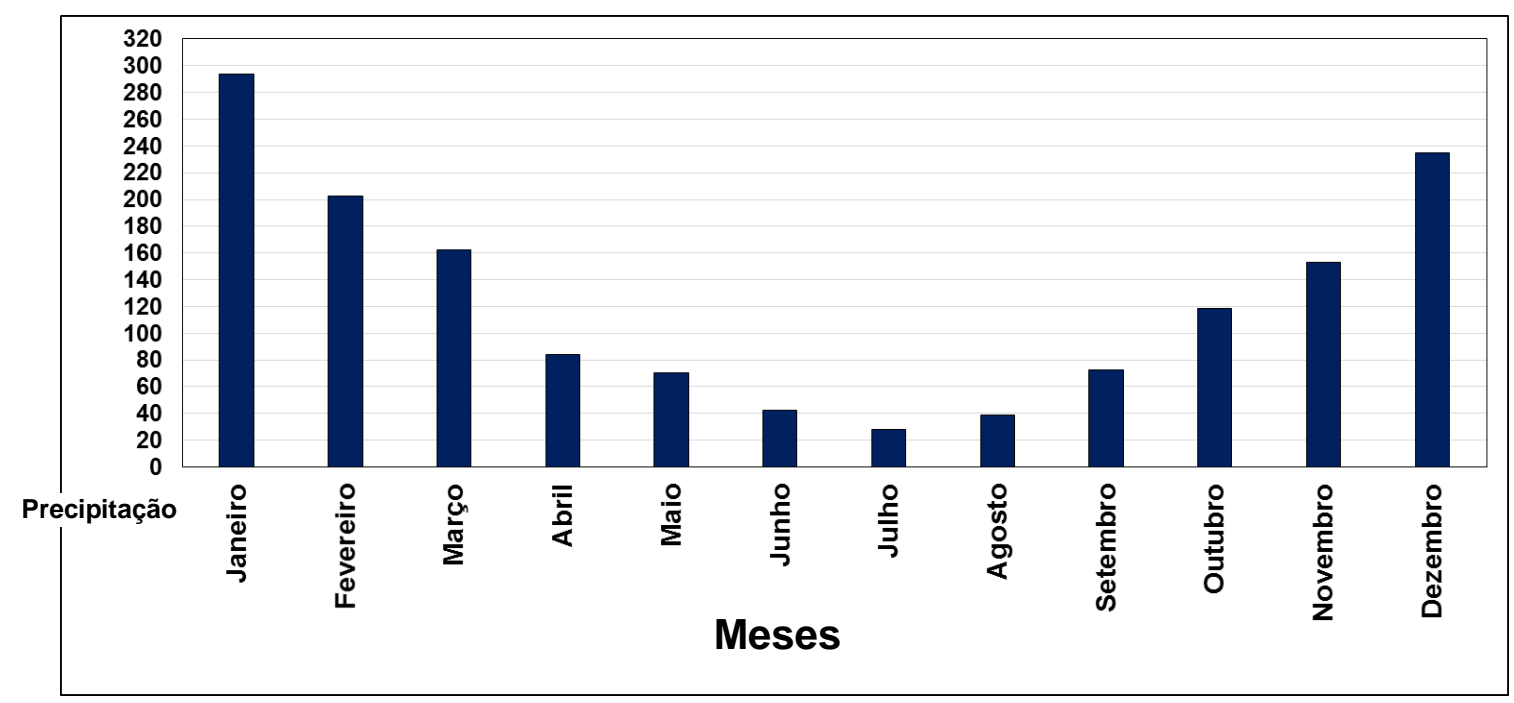

Elaborado pelos autores/2018.

Utilizou-se ainda imagens de satélites para monitoramento da movimentação atmosférica e boletins informativos como aqueles fornecidos pelo CLIMANÁLISE que auxiliaram na identificação dos principais sistemas atmosféricos atuantes no período que foram identificados nas cartas sinóticas ou nas imagens de satélite manuseadas.

A base metodológica utilizada explorou o conceito da dinâmica do clima e dos Anos Padrões elaborado por Monteiro (1971 e 1976) que nomeia como critério para caracterização dos anos cinco classes; os anos extremos são classificados como Seco ou Chuvoso, aqueles situados nas proximidades da média registrada no período como Habituais ou Normais, enquanto que os que apresentam índices situados em patamares um pouco distantes da média mas aquém dos dados mais extremos são definidos como Tendente a Seco ou Tendentes a Chuvoso (complementada pela metodologia exposta na Tabela 1).

Por meio desta análise, obtêm-se a compreensão do comportamento atmosférico sazonal (escala mesoclimática) do período e, assim, delineia-se seu ritmo, sua realidade e sua manifestação na escala local (microclimática) (RIBEIRO, 1993). Para a caracterização da atuação da atmosfera na escala mesoclimática foram consideradas em suas habitualidades as principais massas de ar e sistemas atmosféricos que atuam no Centro-Sul do Brasil (NIMER 1979; VAREJÃO-SILVA, 2000).

Esta metodologia foi utilizada com êxito em alguns trabalhos (ARMANI e GALVANI, 2011; BORSATO e MENDONÇA, 2013) que também buscaram quantificar e caracterizar o ritmo dos sistemas atmosféricos por meio da tabulação dos dados climatológicos de precipitação e análise diária das cartas sinóticas e imagens de satélite; contribuindo de maneira ímpar com a ampliação do conhecimento disponível acerca da dinâmica atmosférica, confirmando, por conseguinte, a eficiência que essa metodologia proporciona para a compreensão do ritmo climático e da sucessão dos diferentes tipos de tempo no espaço geográfico. 
Em seguida ao uso desses procedimentos metodológicos foi utilizada a metodologia dos Anos Padrões a partir dos dados contidos na série histórica contida na estação climatológica do CRHEA da EESC/USP de modo a classificar e caracterizar o comportamento pluviométrico em escalas temporais: sazonal, mensal, diária e episódica. Essa caracterização representa "os diferentes graus de proximidade do ritmo 'habitual' ao lado daqueles afetados por irregularidades na circulação." (MONTEIRO, 1991, p.38).

Portanto, estabelecidos assim, os padrões habituais e excepcionais, obtidos pelo total pluviométrico médio mensal e desvio-padrão que estabelece categorias qualitativas para 0 comportamento da precipitação do período, bem como pela classificação dos anos extremos, estabelece-se os parâmetros da metodologia para delimitar o intervalo de cada classe admitida (Tabela 1).

Tabela 1: Classificação do comportamento pluviométrico em relação à média.

\begin{tabular}{|c|c|}
\hline Classificação & Desvios (+) ou (-) em \% \\
\hline Chuvosos (intervalos de desvios) & $>$ ou $=\mathbf{a}+\mathbf{3 0} \%$ \\
\hline Tendentes a Chuvosos (intervalos de desvios) & $+15 \% \mathbf{a}+\mathbf{3 0} \%$ \\
\hline Normais (intervalo de desvios) & $+15 \% \mathbf{a}-15 \%$ \\
\hline Tendentes a Secos (intervalo de desvios) & $-15 \% \mathbf{a}-30 \%$ \\
\hline Secos (intervalos de desvios) & $>$ ou $=\mathbf{a}-30 \%$ \\
\hline
\end{tabular}

Fonte: Adaptado de Monteiro (1976).

Desta forma, estabelecida a média para a série histórica analisada - nesse caso trinta e quatro anos - ficam estabelecidos os intervalos de cada classe, admitindo-se o patamar de $15 \%$ como referência para o enquadramento; portanto, os anos tidos por Normais deverão possuir índices pluviométricos que não se distanciem da média acima ou abaixo dessa porcentagem. Os anos Tendentes a Seco ou Tendentes a Chuvoso terão como parâmetro o espaço situado acima de $15 \%$ sem ultrapassar o limite de $30 \%$ respectivamente negativo ou positivo, ficando os anos classificados como Secos ou Chuvosos com distanciamento negativo ou positivo superior a $30 \%$ em relação à média histórica observada. Com isso, procura-se visualizar na série a frequência de cada uma das cinco classes mencionadas com o propósito de verificar qual predomina e se o predomínio de extremos é encoberto pela média. Obviamente deve receber atenção o comportamento mensal da precipitação em face dos impactos que pode ocasionar sobre a área.

\section{RESULTADOS}

Frente a média histórica da série analisada e os dados observados a cada ano, verificou-se que a distribuição mensal da precipitação durante o semestre hidrológico 2013-2014 foi irregular e abaixo da média durante dezembro/2013, janeiro/2014, fevereiro/2014 e março/2014, imprimindo teor de excepcionalidade aos meses de outubro e novembro de 2013 pelo fato de seus respectivos índices pluviométricos situarem-se ligeiramente acima da média esperada, como será descrito a seguir.

\section{Outubro 2013}

Outubro é considerado um mês de transição entre as estações seca e chuvosa na porção central do Brasil. Para Nimer (1972), esse caráter de transição climática, sobretudo da Região Sudeste, estabelece sua característica mais importante para o período, devido à alta variabilidade sazonal

$\begin{array}{llllll}\text { Caminhos de Geografia } & \text { Uberlândia - MG } & \text { v. 19, n. } 68 & \text { Dez/2018 } & \text { p. 1-18 } & \text { Página } 5\end{array}$


da precipitação. Além disso, a combinação de mecanismos atmosféricos associados a eventos de chuva sempre ocasiona grandes perdas e prejuízos à população nesta época do ano.

Segundo o Climanálise (2013a), no decorrer do mês, com o estabelecimento da circulação típica do período primavera-verão na América do Sul, ocorreu a formação do canal de umidade entre os estados das regiões Sudeste, Centro-Oeste e Norte do Brasil. Porém, na medida em que os meses se seguiram, verificou-se a partir de dezembro uma tênue formação das áreas de convergência de umidade, ocasionando um déficit pluviométrico nos estados do Centro-Oeste e Sudeste. Dada as características da atmosfera nos meses que se seguiram a outubro e novembro de 2013, não se estabeleceu sobre essas regiões condições típicas que permitissem a caracterização dos clássicos episódios de Zona de Convergência do Atlântico Sul (ZCAS); com isso, a Região do Sudeste registrou totais pluviométricos mensais abaixo da média histórica, com exceção de algumas áreas isoladas, especialmente no centro-norte do estado de São Paulo (Figura 2 a,b).

Figura 2: (a) Precipitação total (mm) e (b) Desvios das médias mensais no mês de outubro/2013. Fonte: Climanálise Boletim (2013a).

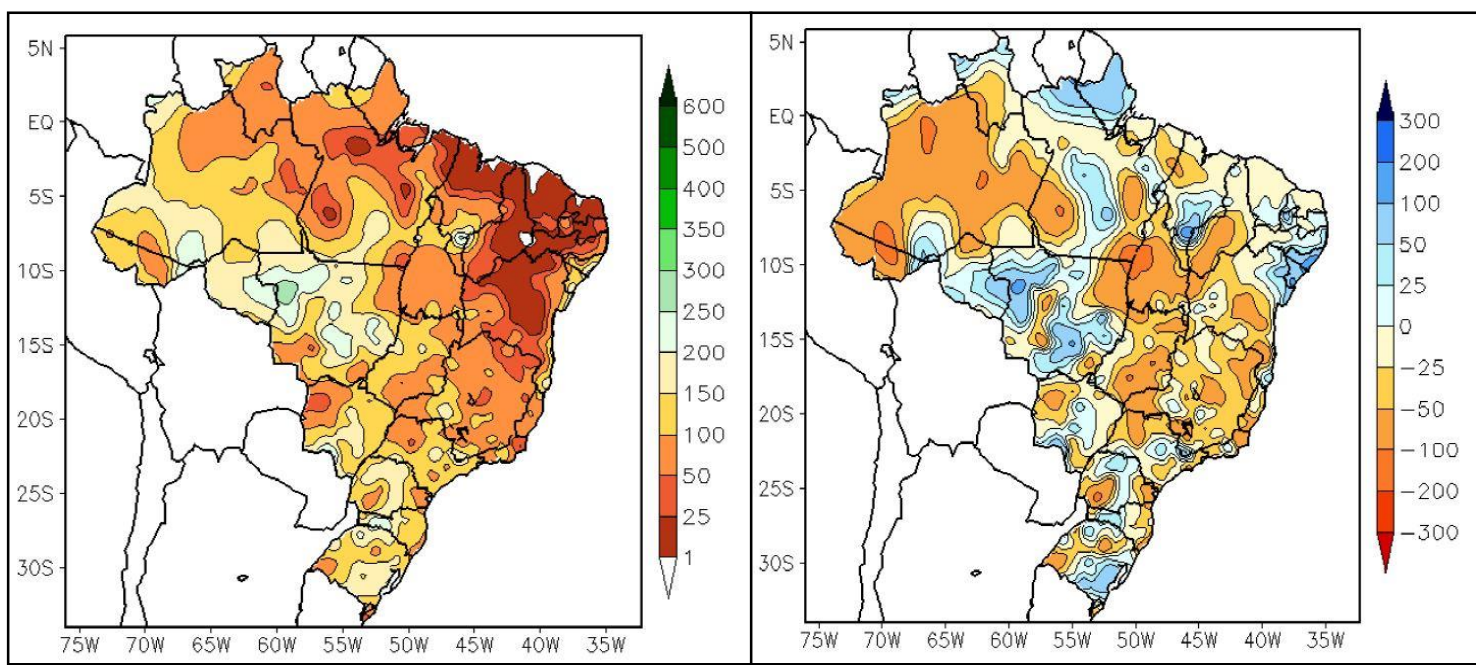

Como é possível observar no Gráfico 2, a manifestação na atmosfera das condições favoráveis à ocorrência da convergência de umidade sobre a área de estudo ocorreu apenas durante os cinco primeiros dias do mês, entre o décimo sexto e décimo nono, e, por fim no vigésimo oitavo. Ainda assim o volume de precipitação foi suficiente para superar a média histórica da série, evidenciando um comportamento diferenciado da precipitação nesse breve período, distante da habitualidade observada na área.

Gráfico 2: Precipitação diária (mm) no mês de outubro/2013 em Itirapina/SP.

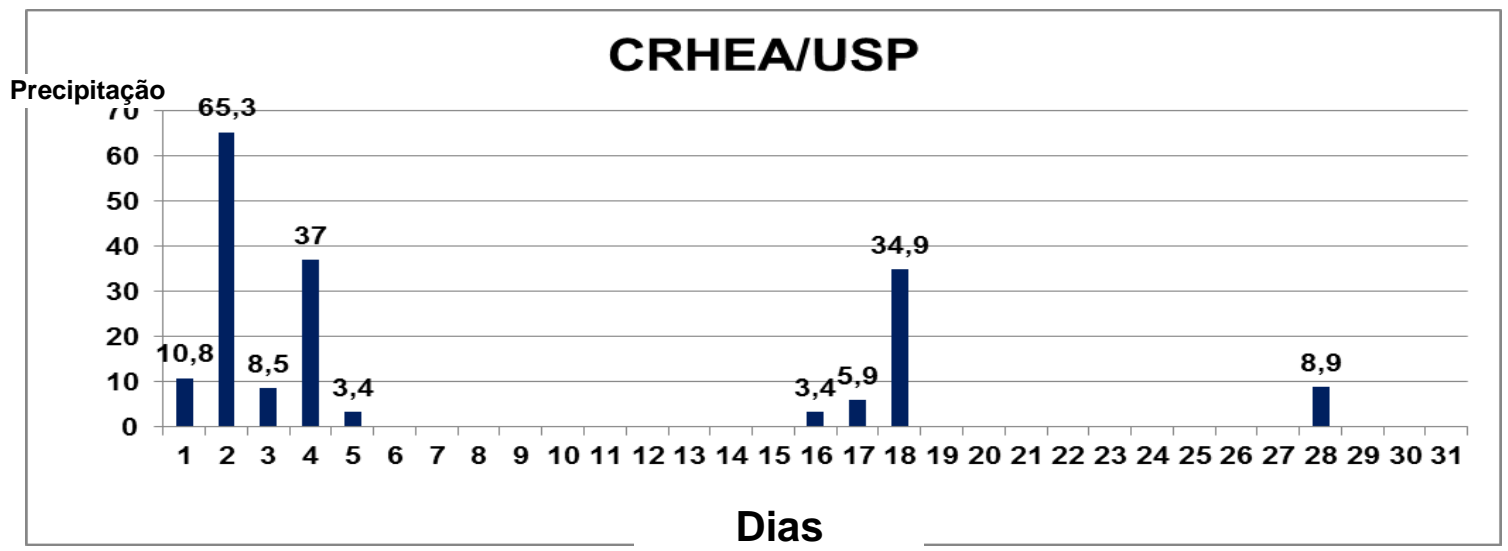

Fonte: Elaborado pelos autores/2018. 
Tabela 2: Precipitação total e média histórica registrada pela estação climatológica no mês de outubro/2013 em Itirapina/SP.

\begin{tabular}{|c|c|}
\hline ESTAÇÕES CLIMATOLÓGICAS & TOTAL DE PRECIPITAÇÃO $(\mathrm{mm})$ \\
\hline CRHEA EESC/USP 2013 & 178,7 \\
\hline Precipitação Média (1980/81-2013/14) & 120,1 \\
\hline
\end{tabular}

Fonte: Elaborado pelos autores/2018.

\section{Novembro 2013}

O mês de novembro marcou o início do estabelecimento do período chuvoso no Brasil, porém os totais pluviométricos mensais mostraram-se abaixo da média histórica em grande parte dessa porção central do território brasileiro (Figura 3 a b), devido a configuração menos intensa da ZCAS sobre a Região Sudeste.

Segundo Climanálise (2013b), a circulação anticiclônica tornou-se mais intensa que o normal sobre o Atlântico Sul nesse período, o que contribuiu para a ocorrência de chuvas acima da média ao longo da costa leste da Região Sudeste do Brasil. As chuvas também excederam a média histórica em áreas isoladas das Sudeste devido à configuração de dois episódios fracos da ZCAS.

No Gráfico 3 é possível observar que a precipitação registrada no mês de novembro protagonizou manifestação em quatro momentos distintos. O primeiro se deu entre o quinto e oitavo dia, o segundo entre o décimo sexto e décimo oitavo, o terceiro entre o vigésimo terceiro e vigésimo sexto, e, o último no trigésimo dia. O primeiro e o terceiro período estão associados a dois eventos tênues de ZCAS. $O$ terceiro momento deveu-se a passagem de uma frente fria na região, enquanto o quarto esteve associado a conjuntura estabelecida pela formação de um cavado. Com isso foram dezessete dias de tempo estável e treze dias com instabilidade e precipitação somada de $199 \mathrm{~mm}$.

Figura 3: (a) Precipitação total $(\mathrm{mm})$ e (b) desvios das médias mensais para novembro/2013. Fonte: Climanálise (2013b).

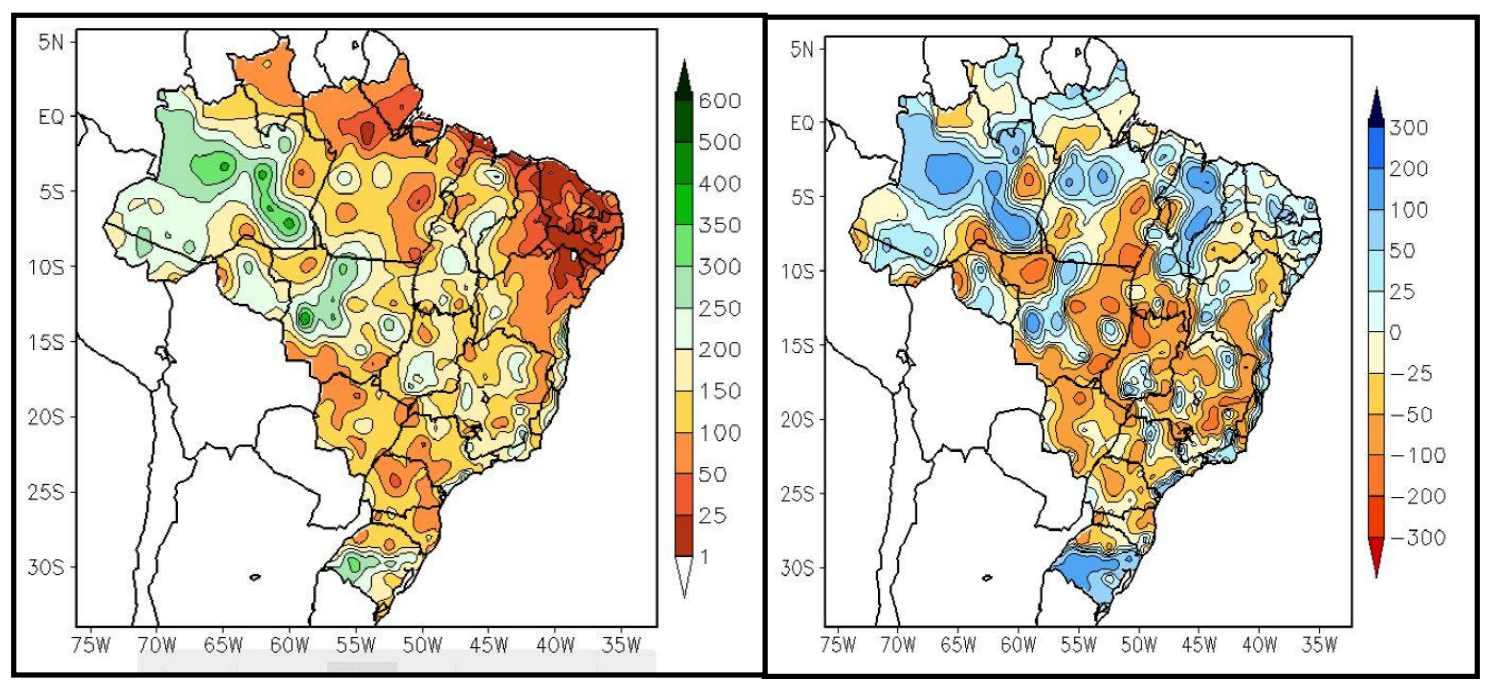

Assim, a chuva acumulada durante o mês de novembro, segundo os dados registrados pela estação do CRHEA EESC/USP, esteve como no mês anterior, acima do valor obtido na média histórica da série (Tabela 3). 
Gráfico 3: Precipitação diária $(\mathrm{mm})$ no mês de novembro/2013 em Itirapina/SP.

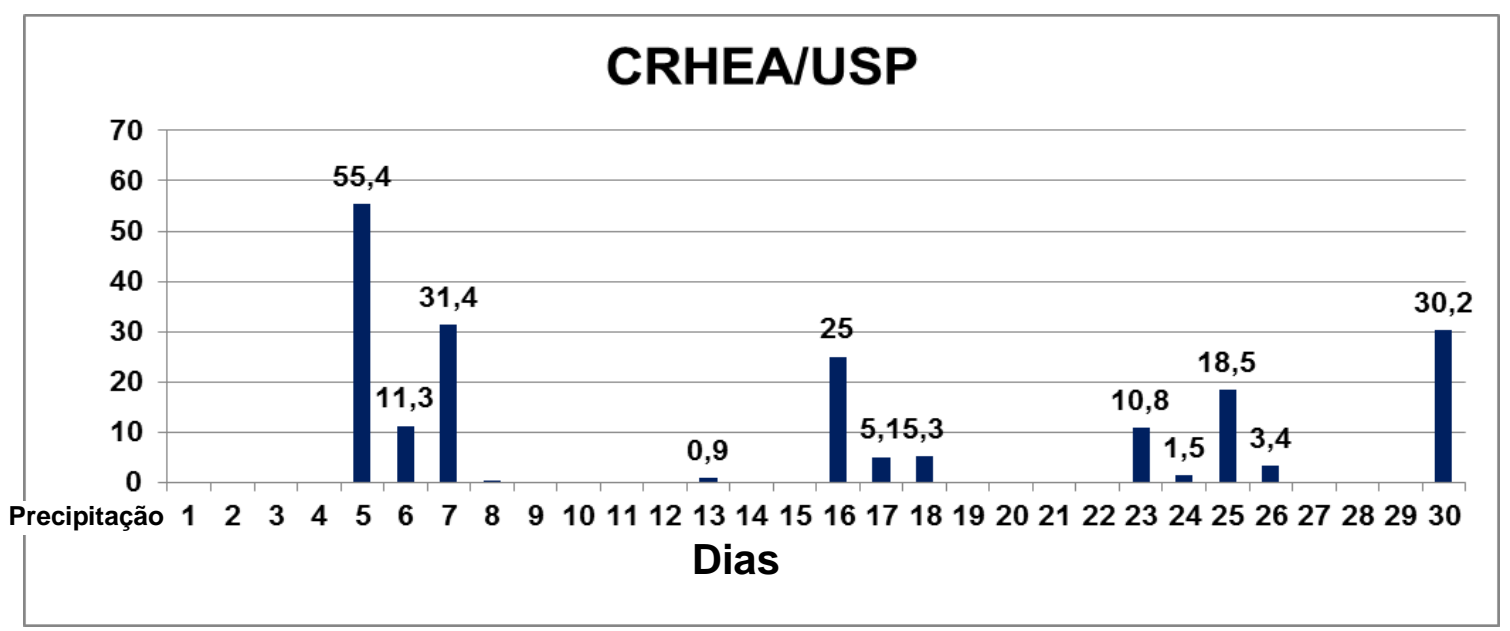

Fonte: Elaborado pelos autores/2018.

Tabela 3: Precipitação total e média histórica registrada pela estação climatológica no mês de novembro/2013 em Itirapina/SP.

\begin{tabular}{|c|c|}
\hline ESTAÇÕES CLIMATOLÓGICAS & TOTAL DE PRECIPITAÇÃO $(\mathrm{mm})$ \\
\hline CRHEA/USP 2013 & 199 \\
\hline Precipitação Média (1980/81-2013/14) & 154,3 \\
\hline
\end{tabular}

Fonte: Elaborado pelos autores/2018.

Portanto, durante todo o mês de novembro o acumulado mensal registrou um valor acima da normal climatológica (média) para região de Itirapina/SP, apesar dos índices registrados nas diversas regiões do Sudeste terem sido abaixo da normal climatológica. Isso deixa claro que a área de estudo apresentou particularidades em relação a conjuntura atmosférica que apresentou no referido período, demandando novo estudo ocupado com a identificação das variáveis que pesaram nesse sentido, criando uma "ilha de umidade" num contexto pautado nesse período em específico pela queda no índice de precipitação.

\section{Dezembro 2013}

O mês de dezembro mostrou-se adverso em precipitação para o estado de São Paulo, Sul e Triângulo de Minas Gerais; entretanto, no restante da Região Sudeste os índices estiveram acima da média, ocasionando em algumas porções do Leste Mineiro e Espírito Santo inundações e alagamentos. Além dessas três áreas, os estados da Região Sul e o Mato Grosso do Sul também se ressentiram com a diminuição das chuvas (Figura 4 a,b).

Observou-se ainda um expressivo aumento no volume da precipitação ocorrida sobre a Região Nordeste e uma queda na Região Norte, demonstrando com isso toda a instabilidade presente nos padrões atmosféricos da América do Sul.

Segundo o Climanálise (2013c), a formação de regiões de convergência de umidade ocorreu em dois períodos no mês de dezembro, mas apenas o segundo episódio evoluiu para uma configuração clássica de ZCAS, resultando em acumulados de chuvas bastante expressivos sobre as Regiões Norte do Sudeste. 
Figura 4: (a) Precipitação total $(\mathrm{mm})$ e (b) desvios das médias mensais para dezembro/2013. Fonte: Climanálise (2013b).

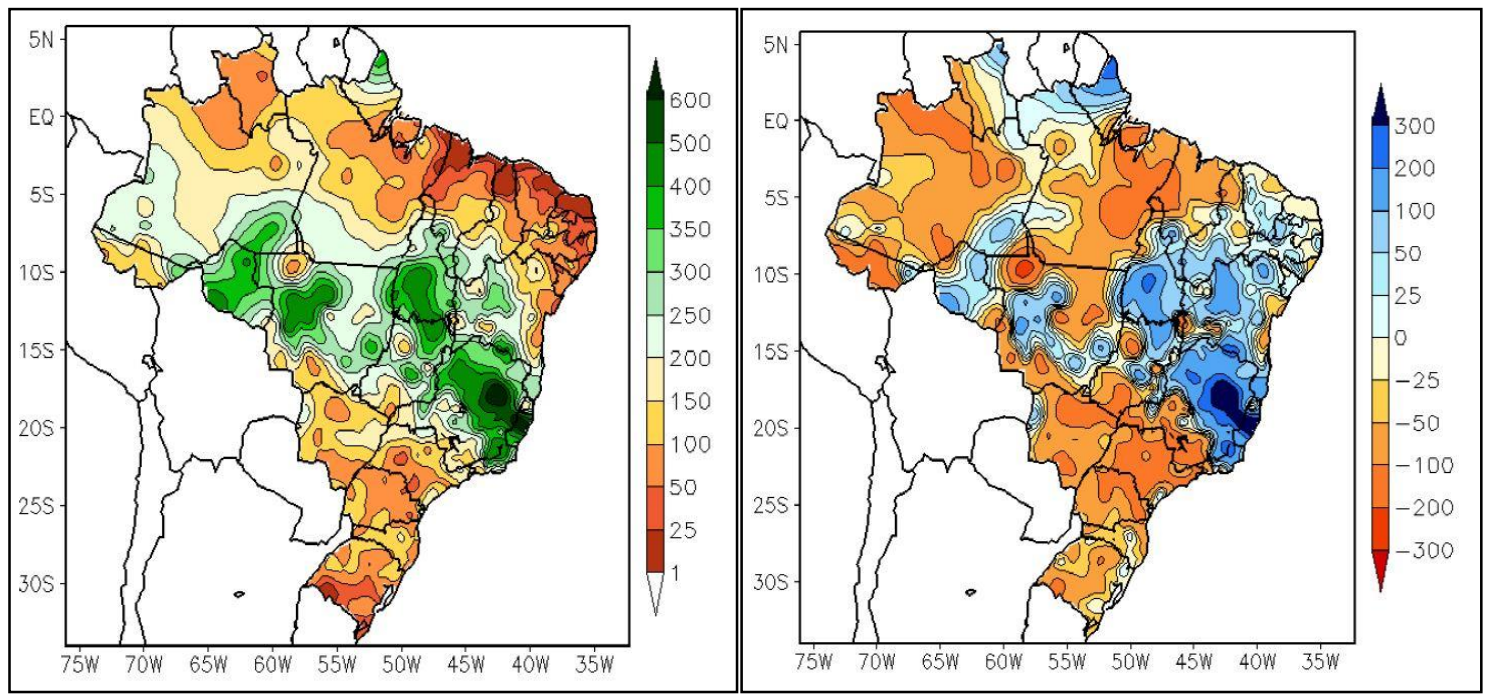

No Gráfico 4 pode ser observado dois períodos de precipitação. Estão relacionados a convergência de umidade estabelecida em dois momentos prolongados do mês de dezembro. $O$ primeiro manifesta-se entre o primeiro e o décimo segundo dia. Caracteriza um momento de chuvas reduzidas. $O$ segundo inicia-se no vigésimo primeiro dia e segue até o trigésimo primeiro. Também ressente-se da baixa pluviosidade com exceção do último dia mês.

Gráfico 4: Precipitação diária (mm) no mês de dezembro/2013 em Itirapina/SP.

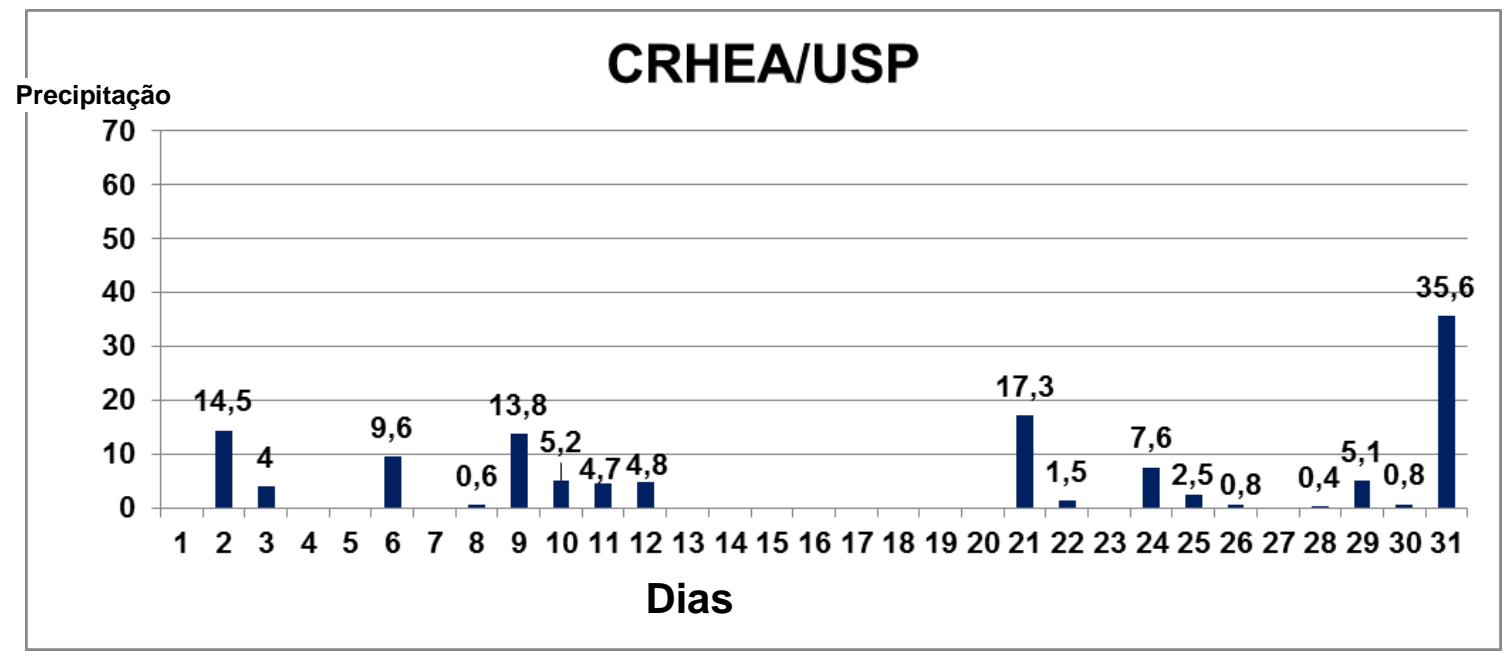

Fonte: Elaborado pelos autores/2018.

Devida a tênue formação da convergência de umidade sobre a área de estudo no referido período, sua precipitação acumulada chegou a $129 \mathrm{~mm}$, situando-se num patamar significativamente abaixo do apresentado pelos meses anteriores (outubro e dezembro), assim como para a média anotada na série histórica considerada que alcançou $234,9 \mathrm{~mm}$ que possui duas vezes o índice registrado em 2013. Diante disto, evidencia-se um momento atípico para a área (Tabela 4).

Portanto, durante todo o mês de dezembro os acumulados registraram valores abaixo da normal climatológica (média) para estação do CRHEA, assim como para toda a região do estado de São Paulo registrando precipitação abaixo do esperado para esse período do ano, ocasionando uma 
série de transtornos para a sociedade e meio ambiente, que se viram envolvidos por um cenário de escassez hídrica agravado pela condição térmica.

Tabela 4: Precipitação total e média histórica registrada pela estação climatológica no mês de dezembro/2013 em Itirapina/SP.

\begin{tabular}{|c|c|}
\hline ESTAÇÕES CLIMATOLÓGICAS & TOTAL DE PRECIPITAÇÃO $(\mathrm{mm})$ \\
\hline CRHEA EESC/USP 2013 & 129 \\
\hline Precipitação Média (1980/81-2013/14) & 234,9 \\
\hline
\end{tabular}

Fonte: Elaborado pelos autores/2018.

\section{Janeiro 2014}

No mês de janeiro a precipitação ficou abaixo da média na maior parte do Brasil. Na Região Sudeste as chuvas foram mais escassas graças à presença de um bloqueio atmosférico, resultando, entre outros fatores, na ausência do episódio bem configurado da ZCAS. A ausência deste sistema contribuiu para a redução da pluviosidade na maior parte do Brasil em janeiro de 2014 (Figura 5b).

Segundo Climanálise (2014a), a manifestação de um bloqueio atmosférico sobre o Pacífico Sul, no decorrer do mês de dezembro de 2013, esteve aliada à atuação de sistemas transientes que se organizam na média e alta troposfera sobre a América do Sul e Atlântico adjacente, como os vórtices ciclônicos (VNE - Vórtice do Nordeste) na alta troposfera e a circulação anticiclônica anômala (ASASAnticiclone Subtropical do Atlântico Sul) na média e alta troposfera, resultando na inibição de episódios clássicos de ZCAS com consequente redução da precipitação na maior parte do Brasil, principalmente sobre o Sudeste.

Segundo Reboita et al. (2010) a atuação da ASAS está associado a baixos índices pluviométricos, principalmente no inverno, quando o sistema alcança sua posição mais a Oeste da América do Sul, se estendendo até a região sudeste do Brasil, estabelecendo um bloqueio atmosférico na área diminuindo significativamente a pluviosidade para prejuízo dos ecossistemas e atividades antrópicas.

Figura 5: (a) Precipitação total $(\mathrm{mm})$ e (b) Desvios das médias mensais para o mês de janeiro/2014. Fonte: Climanálise Boletim (2014a).

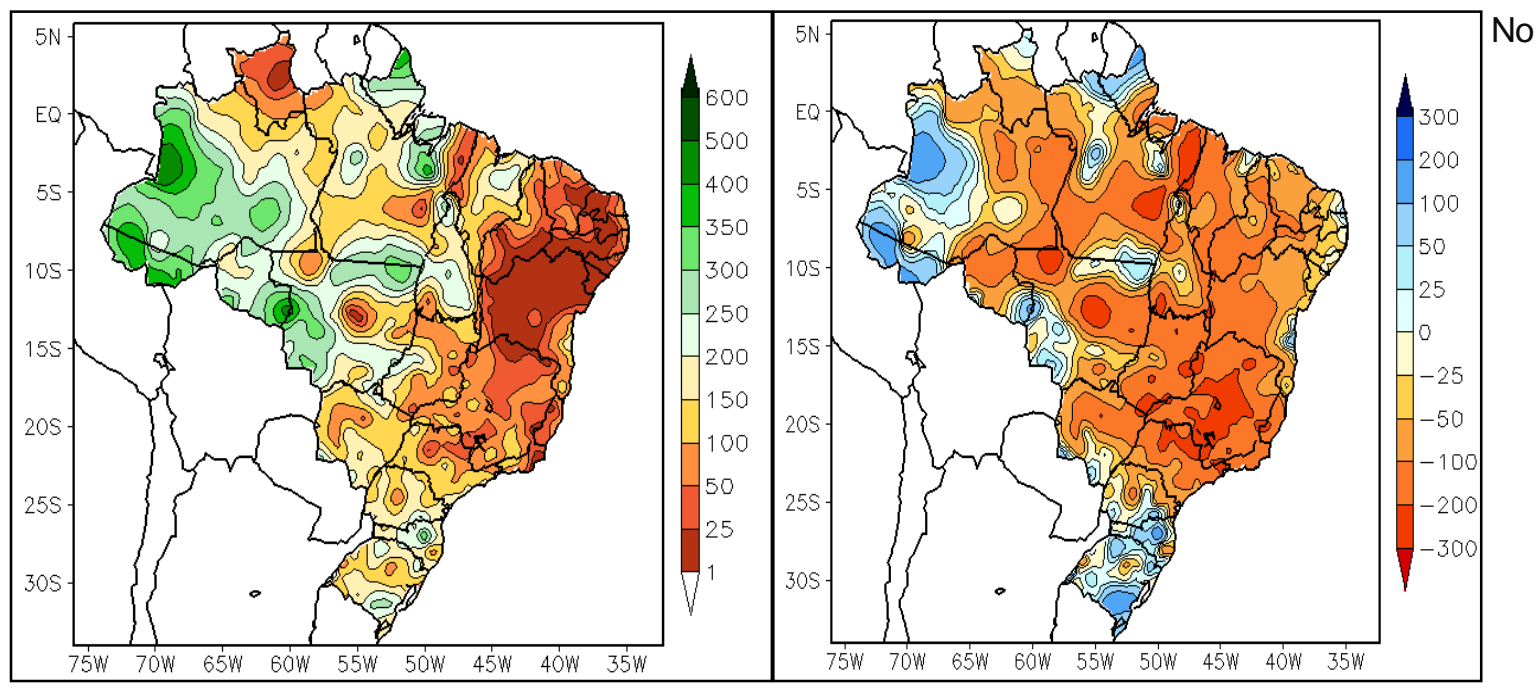


Gráfico 5 pode ser observada a ocorrência de precipitação ao longo do mês de janeiro de 2014. Mais uma vez, a exemplo daquilo que ocorreu em dezembro de 2013, verifica-se uma baixa pluviosidade. Ao longo do mês as chuvas manifestaram-se em três momentos distintos; o primeiro entre o primeiro e o sexto dia do mês com um breve hiato no terceiro e quarto dias; o segundo iniciando-se no décimo terceiro dia e prosseguindo até o décimo oitavo; por fim, o terceiro está limitado a dois dias específicos, o vigésimo terceiro e vigésimo quinto. Seguindo o padrão iniciado no mês anterior, a precipitação sofre sensível redução. Isto deve-se a ação do bloqueio atmosférico que dificultou a formação da convergência de umidade na atmosfera da área para do Sudeste do Brasil e outras porções do território brasileiro.

Gráfico 5: Precipitação diária (mm) no mês de janeiro/2014 em Itirapina/SP.

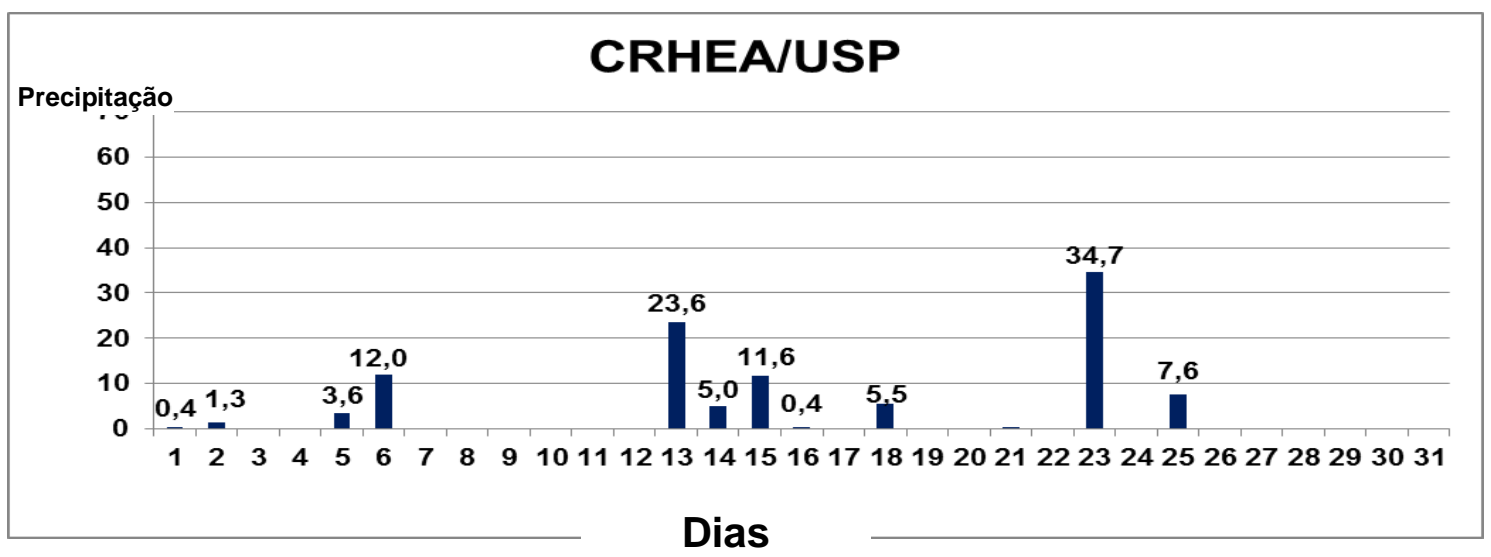

Fonte: Elaborado pelos autores/2018.

Assim, as chuvas acumuladas durante o mês de janeiro de 2014 para região de Itirapina/SP, alcançaram um total de $106 \mathrm{~mm}$ para estação do CRHEA/USP, situando-se mais uma vez significativamente abaixo da média histórica (Tabela 5).

Portanto, durante todo o mês de janeiro de 2014 o acumulado mensal registrou valores abaixo da normal climatológica (média) para região do estado de São Paulo com chuvas abaixo de $50 \%$ do índice médio para o período segundo os dados analisados da série histórica, reforçando a tese de comprometimento da habitualidade atmosférica da área nessa porção da América do Sul.

Tabela 5: Precipitação total e média histórica registrada pela estação climatológica no mês de janeiro/2014 em Itirapina/SP.

\begin{tabular}{|c|c|}
\hline ESTAÇÕES CLIMATOLÓGICAS & TOTAL DE PRECIPITAÇÃO $(\mathrm{mm})$ \\
\hline CRHEA/USP 2014 & 106 \\
\hline Precipitação Média (1980/81-2013/14) & 303,3 \\
\hline
\end{tabular}

Fonte: Elaborado pelos autores/2018.

\section{Fevereiro 2014}

No mês de fevereiro, segundo o Climanálise (2014b), a ausência de episódios bem configurados da ZCAS, em parte associada, entre outros aspectos, ao posicionamento da ASAS sobre o interior do continente, contribuiu para a escassez de chuva na maior parte das Região Sudeste do Brasil (Figura 6b). 
No Gráfico 6 do mês de fevereiro de 2014 a precipitação apresentou-se mais uma vez fora do padrão habitual que caracteriza o Clima Tropical de Altitude da área. Na primeira metade do mês ocorreram quatro dias com chuvas com baixo índice pluviométrico, enquanto que no restante do mês a precipitação tem um aumento significativo em sete dias de chuvas com destaque ao décimo sexto, vigésimo oitavo, e, sobretudo, vigésimo sexto.

Figura 6: (a) Precipitação total (mm) e (b) Desvios das médias mensais no mês de fevereiro/2014. Fonte: Climanálise Boletim (2014b).

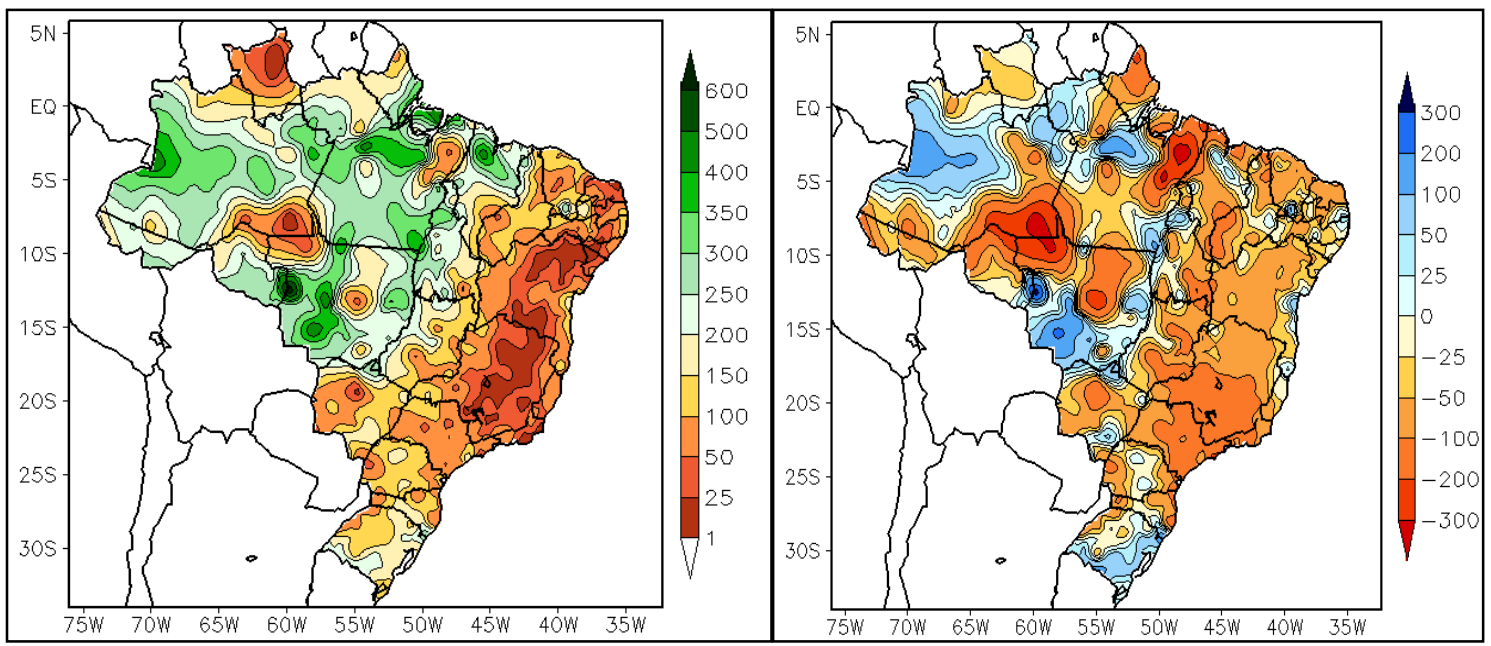

A pluviosidade registrada ao longo do mês contou com uma manifestação tênue de ZCAS, devido ao deslocamento de um sistema frontal entre os dias quatorze e dezessete. Entre os dias vinte e quatro e vinte e oito uma convergência de umidade manifestou-se sobre a região favorecendo a ocorrência da maior precipitação que foi registrada no dia vinte e seis.

Assim, a precipitação total do mês de fevereiro para região de Itirapina/SP foi de $158 \mathrm{~mm}$ para estação do CRHEA/USP, situando-se expressivamente abaixo da média obtida na série histórica. Mais uma vez o quadro esteve distante da habitualidade reforçando o perfil atípico do período frente os anos anteriores (Tabela 6).

Gráfico 6: Precipitação diária $(\mathrm{mm})$ no mês de fevereiro/2014 em Itirapina/SP.

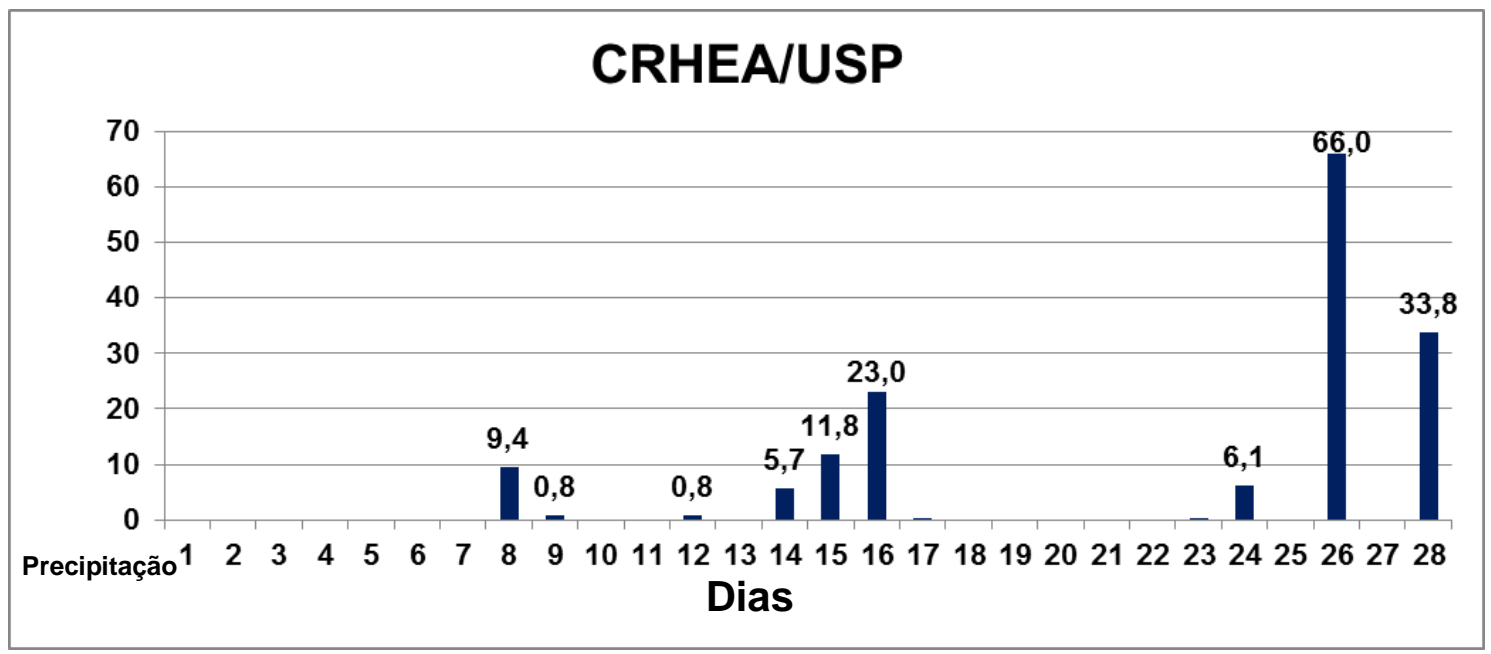

Fonte: Elaborado pelos autores/2018. 
Outro aspecto reforçado pelo comportamento da precipitação no mês de fevereiro diz respeito à importância da movimentação atmosférica no provimento de umidade para essa porção do território brasileiro, destacando, por conseguinte, como a ZCAS e sistemas de convergência de umidade constituem parte fundamental da conjuntura atmosférica na área de estudo.

Tabela 6: Precipitação total e média histórica registrada pela estação climatológica no mês de fevereiro/2014 em Itirapina/SP.

\begin{tabular}{|c|c|}
\hline ESTAÇÕES CLIMATOLÓGICAS & TOTAL DE PRECIPITAÇÃO $(\mathrm{mm})$ \\
\hline CRHEA EESC/USP 2013 & 158 \\
\hline Precipitação Média (1980/81-2013/14) & 201,5 \\
\hline
\end{tabular}

Fonte: Elaborado pelos autores/2018.

\section{Março 2014}

No mês de março segundo o Climanálise (2014c), as chuvas continuaram abaixo da média em grande parte da Região Sudeste. Também neste mês, o posicionamento dos vórtices ciclônicos na alta troposfera, próximo e sobre a costa leste da América do Sul, inibiu a formação de episódios bem configurados da ZCAS resultando na persistência de precipitação abaixo da normal climatológica na maior parte da Região Sudeste. Nesse mês a situação sofre alteração em Mato Grosso do Sul e estados da Região Sul, mantendo-se inalterada apenas no Sudeste para agravamento do abastecimento de água (Figura 7).

Figura 7: (a) Precipitação total ( $\mathrm{mm}$ ) e (b) Desvios das médias mensais no mês de março/2014. Fonte: Climanálise Boletim (2014c).

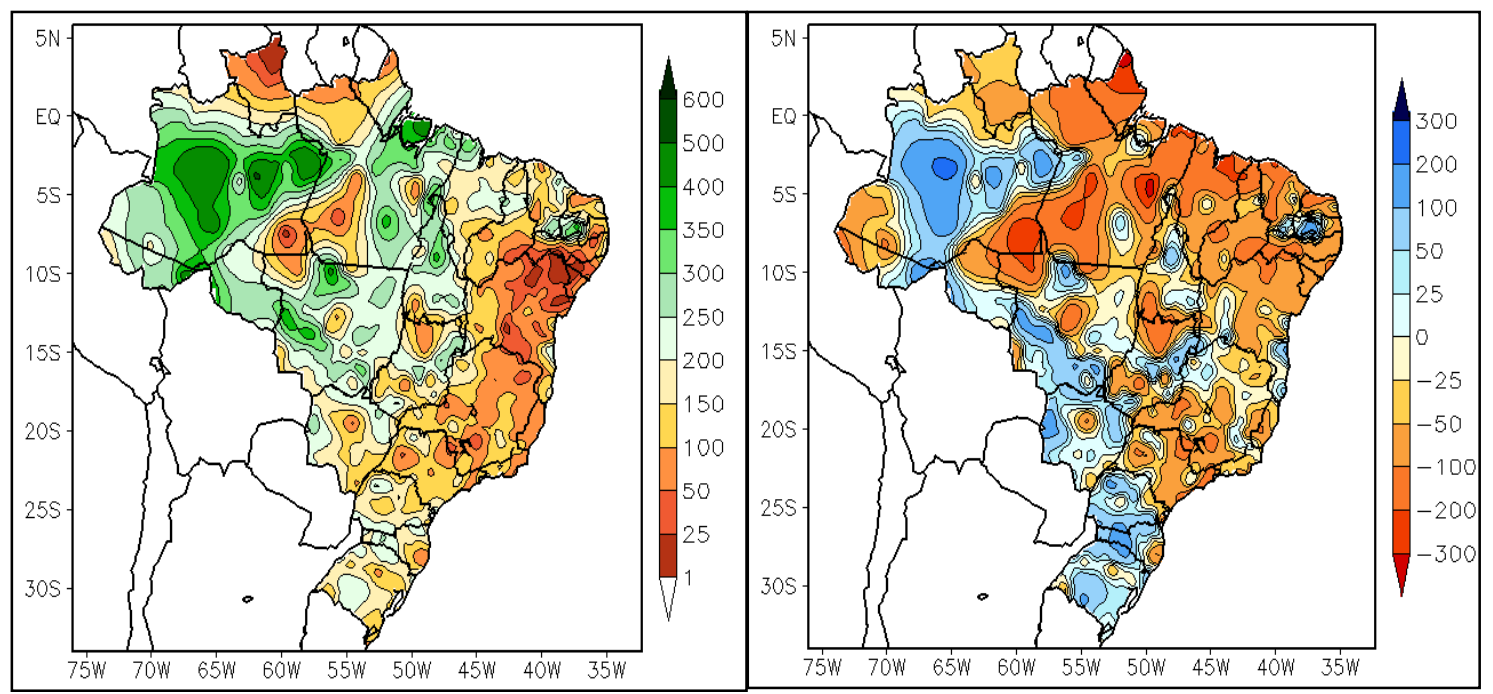

O Gráfico 7 mostra um evento de chuvas ocorrido na primeira quinzena devido a fraca formação de zonas de convergência de umidade entre o primeiro e segundo dias, quinto e nono, assim como no décimo segundo e décimo terceiro. Entre vigésimo e vigésimo segundo dia a precipitação registrada decorreu da passagem de um sistema frontal.

Assim, a precipitação acumulada durante o mês de março para região de Itirapina/SP registrou 142,8 $\mathrm{mm}$ na estação do CRHEA/USP. Caracterizando mais uma vez a situação atípica onde o índice de pluviosidade situa-se significativamente abaixo da média histórica obtida para a área (Tabela 7). 
Portanto, durante todo o mês de março de 2014 o acumulado mensal registrou valores abaixo da normal climatológica (média) para a área de estudo com base nos dados analisados da série histórica, reforçando a tese de comprometimento da habitualidade atmosférica dessa porção da América do Sul devido uma conjuntura diferenciada que ocasionou entre outros, racionamento no abastecimento urbano de água e diminuição na oferta de recursos hídricos para o desenvolvimento satisfatório das atividades antrópicas urbanas e rurais.

Gráfico 7: Precipitação diária no mês de março/2014 em Itirapina/SP.

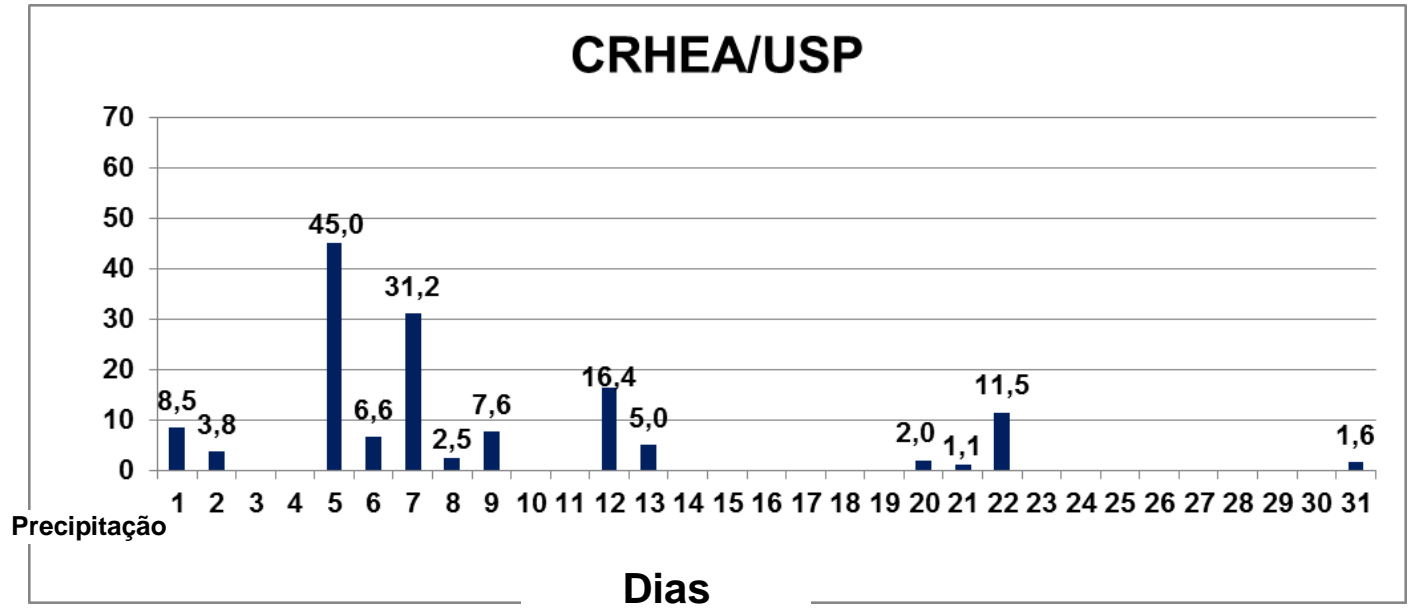

Fonte: Elaborado pelos autores/2018.

Tabela 7: Precipitação total e média histórica registrada pela estação climatológica no mês de março/2014 em Itirapina/SP.

\begin{tabular}{|c|c|}
\hline ESTAÇÕES CLIMATOLÓGICAS & TOTAL DE PRECIPITAÇÃO (mm) \\
\hline CRHEA EESC/USP 2013 & 142,8 \\
\hline Precipitação Média (1980/81-2013/14) & 167,1 \\
\hline
\end{tabular}

Fonte: Elaborado pelos autores/2018.

\section{CARACTERIZAÇÃO DO PERÍODO CHUVOSO 2013/2014}

O semestre hidrológico de outubro/2013 a março/2014 foi avaliado ainda através da metodologia dos Anos Padrões (MONTEIRO, 1971 e 1976), buscando verificar em qual classe a precipitação registrada no período poderia ser classificada, a saber, Normal, Tendente a Seco, Seco, Tendente a Chuvoso, e, Chuvoso. Nesse processo procurou-se ainda identificar os momentos que apresentaram maiores e menores ocorrências situadas como notórias ou atípicas (Gráfico 8).

Segundo foi possível observar na série histórica iniciada em 1980 e encerrada em 2014, a média pluviométrica esteve em $1.181,5 \mathrm{~mm}$, consequentemente, índices situados em até 15\% acima ou abaixo desse valor caracterizam Anos Normais; registros situados entre $15 \%$ e $30 \%$ abaixo da média são identificados como Tendentes a Seco; valores abaixo de 30\% são nomeados Secos; índice situado entre $15 \%$ e $30 \%$ acima corresponde a Tendentes a Chuvoso; e, resultados situados acima de $30 \%$ são definidos como Chuvosos.

Para Peixoto (1987, p.15), "a variabilidade climática refere-se a intervalos de tempo a que se pode associar uma causa definida menor e incluir os valores extremos e as diferenças entre valores médios anuais, sazonais, mensais", portanto, o que se observa no comportamento da precipitação da área de estudo ao longo da série de anos considerada no estudo precisa ser analisado sob essa perspectiva. 
Gráfico 8: Desvio da média de precipitação do período de 1980/81-2013/14 conforme dados da Estação CRHEA EESC/USP em Itirapina/SP.

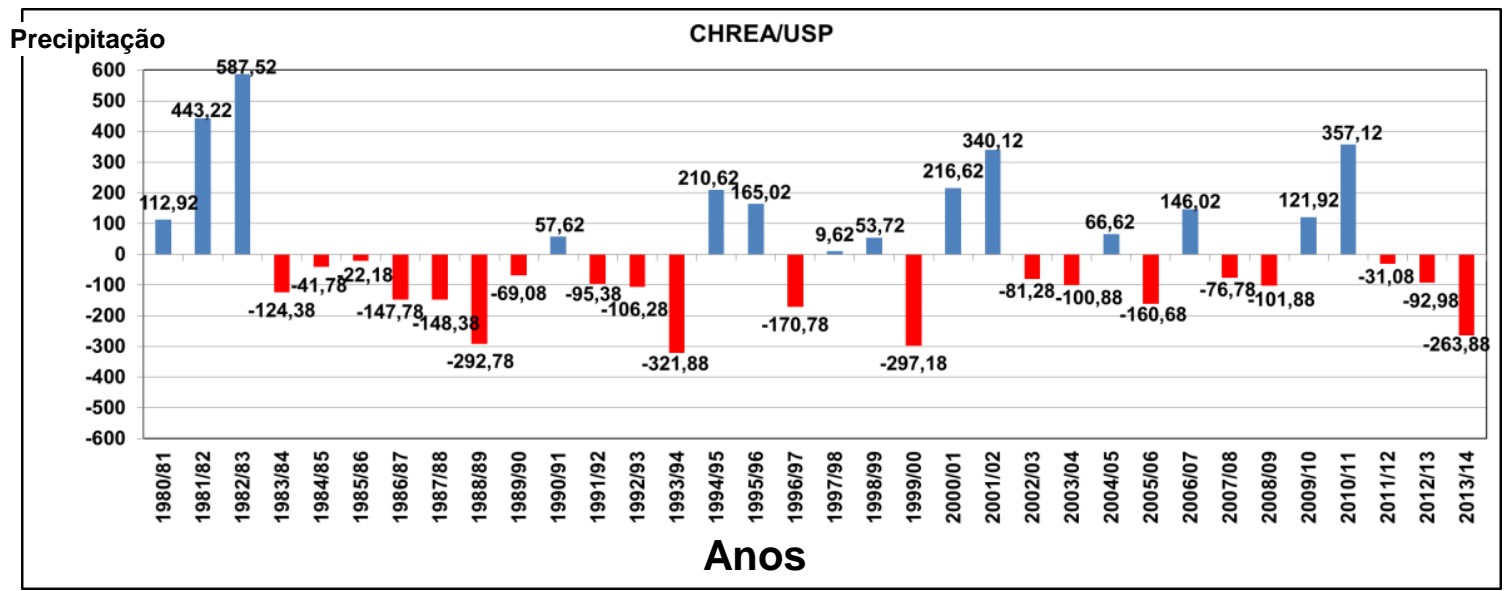

Fonte: Elaborado pelos autores/2018.

Analisando os dados com base na metodologia adotada e no paradigma mencionado, pode-se observar que a ordem de frequência com maior ocorrência foram os semestres classificados como Normais $(\mathrm{N})$ que apresentaram valores de precipitação com desvios variando entre $-15 \% \mathrm{e}+15 \%$, respectivamente os períodos de 1980/1981, 1983/1984, 1984/1985, 1985/1986, 1986/1987, 1987/1988, 1989/1990, 1990/1991, 1991/1992, 1992/1993, 1995/1996, 1996/1997, 1997/1998, 1998/1999, 2002/2003, 2003/2004, 2004/2005, 2005/2006, 2006/2007, 2007/2008, 2008/2009, 2009/2010, 2011/2012 e 2012/2013.

Neste sentido, o número de ocorrências de semestres situados nessa classificação foi de vinte e quatro vezes, representando percentualmente $70,58 \%$ da precipitação ocorrida na série histórica considerada. A segunda maior ordem de ocorrência foram os semestres identificados como Tendentes a Seco (TS) que apresentaram valores com desvios negativos na precipitação variando entre $-15 \%$ e $-30 \%$, especificamente os períodos de 1988/1989, 1993/1994, 1999/2000 e 2013/2014. Foram quatro ocorrências dos semestres inseridos nessa classificação, representando percentualmente $11,76 \%$ da precipitação ocorrida na área de estudo.

A Tabela 8 sintetiza os dados, permitindo visualizar o número de ocorrência que os períodos chuvosos classificados apresentaram, e, a consequente ordem de frequência na série.

Tabela 8: Frequência dos tipos de classes ocorridas no período de 1980/81- 2013/14 em Itirapina/SP.

\begin{tabular}{|c|c|c|c|}
\hline Tipo & № de ocorrência & Porcentagem & Ordem de frequência \\
\hline $\mathbf{N}$ - Normais & 24 vezes & $70,58 \%$ & 10 \\
\hline TS - T. Secos & 4 vezes & $11,76 \%$ & 2 \\
\hline C-Chuvosos & 3 vezes & $8,83 \%$ & 3은 \\
\hline TC - T. Chuvosos & 3 vezes & $8,83 \%$ & 3은 \\
\hline S-Secos & --------- & ---------- & --- \\
\hline TOTAL & 34 semestres & $100 \%$ & \\
\hline
\end{tabular}

Fonte: Adaptado de Monteiro (1976). 


\section{CONCLUSÕES}

Conforme foi possível observar, a atuação dos sistemas atmosféricos no período chuvoso de 2013/2014 ocorreu fora dos parâmetros que caracterizam a habitualidade atmosférica da área de estudo, atestando, por conseguinte, todo cuidado que deve existir quando se procura associar tais situações excepcionais a um quadro maior de mudanças climáticas. Seguramente o índice pluviométrico registrado não favoreceu o abastecimento de água à população e a recarga dos recursos hídricos da área, todavia, não obstante a isto, manteve-se sujeito ao padrão identificado na série histórica analisada 1980/1981-2013/2014 afastando por hora a perspectiva de uma mudança na conjuntura atmosférica da área de estudo.

Em relação aos registros da precipitação que foram analisados e as correlações mantidas com os pares da série histórica, é possível observar que o comportamento das chuvas no período específico 2013/2014 (meses de outubro, novembro e dezembro de 2013 e janeiro, fevereiro e março de 2014) apresentou-se irregular com índices superiores à média nos meses de outubro/2013 e novembro/2013, e, valores significativamente abaixo nos meses de dezembro/2013, janeiro/2014, fevereiro/2014 e março/2014; sem, a presença de um único momento de transição onde os dados estivessem compatíveis com a média histórica.

Nos dois primeiros meses do semestre hidrológico a precipitação apresentou-se superior à média na ordem de $30 \%$, enquanto que nos meses seguintes alcançou patamares situados abaixo de $30 \%$ da média com extremos que chegaram ao nível de mais de $50 \%$ de queda como é o caso do mês de dezembro/2013 e janeiro/2014. Seguramente a formação de bloqueio atmosférico (ASAS) impedindo a formação do processo de frontogênese e a configuração da Zona de Convergência do Atlântico Sul (ZCAS) foi fundamental para essa queda expressiva no índice pluviométrico da área nos últimos quatro meses do período úmido estudado.

Segundo indicam os boletins e cartas sinóticas consultadas para entendimento da conjuntura atmosférica da área de estudo no semestre hidrológico 2013/2014, a movimentação atmosférica esteve influenciada pela intensificação da circulação anticiclônica (ASAS) sobre o Atlântico Sul nas imediações do litoral da América do Sul, resultando, consequentemente, numa tênue manifestação de convergência de umidade. A esse quadro soma-se o bloqueio atmosférico mais eficiente que dificultou a entrada de sistemas frontais vindas da porção Sul e, também, impedindo a entrada de massas de ar transportando umidades vindas da porção Norte.

Diante da situação estabelecida a partir da diminuição da pluviosidade da área, tornam-se importantes estudos sobre entender o funcionamento e gênese desse tipo de movimentação atmosférica para que se possa antever novas ocorrências e assim informar à sociedade acerca do possível cenário e das condições que serão predominantes durante sua duração.

Obviamente o comportamento da precipitação no período dificultou a ação e percepção dos agentes públicos frente as previsões anunciadas, em razão do índice pluviométrico dos dois primeiros meses apresentar-se acima da média histórica, contradizendo as ressalvas que eram comunicadas pelos pesquisadores acerca da estiagem que se apresentaria na área; no entanto, não obstante a essa compreensível dúvida que poderia se estabelecer na mente dos gestores públicos ou dirigentes das companhias de abastecimento, não é suficiente para justificar a ausência de um plano emergencial previamente concebido para adoção em situações como essa.

Isso é sério e grave, pois sinaliza que tais agentes não estão preocupados com a responsabilidade que assumiram ao ocuparem a função que exercem frente a estrutura do Estado (nos seus diversos níveis - municipal, estadual e federal) ou das empresas privatizadas que atuam na captação, tratamento e distribuição de água tratada a população.

Pelo que se pode observar nos dados coletados na estação do CRHEA EESC/USP em Itirapina/SP, tem-se na série histórica uma média aproximada de $70,5 \%$ de Anos Normais com índices pluviométricos próximos à média da série histórica, 11,7\% de Anos Tendentes a Seco, e, $8,8 \%$ de Anos Tendentes a Chuvoso ou Chuvoso; denunciando que acima da queda da precipitação em alguns momentos, pesa, sobre as adversidades vivenciadas pela sociedade a ausência de um plano de ação que contemple esse tipo de conjuntura que é extraordinária - cerca de $11,7 \%$. 


\section{AGRADECIMENTOS}

Expressamos nosso agradecimento ao CNPq pela bolsa de mestrado concedida para a realização da pesquisa que embasou a redação desse artigo, e, ainda ao CRHEA da EESC/USP e seu Núcleo de Estudos Climatológicos pelo apoio no compartilhamento dos dados registrados em sua Estação meteorológica e cessão de sua estrutura para estudos.

\section{REFERÊNCIAS}

ARMANI, G.; GALVANI, E. Fluxos polares e o ritmo dos sistemas atmosféricos no Nordeste do estado de São Paulo. Revista Sociedade \& Natureza, Uberlândia, v. 23, n. 1, p. 7-22, abr. 2011. https://doi.org/10.1590/S1982-45132011000100002

BORSATO, V. A.; MENDONÇA, F. A. A Dinâmica dos sistemas atmosféricos no verão 2012-2013 no Paraná e em Campo Mourão. In: SIMPÓSIO DE ESTUDOS URBANOS: a dinâmica das cidades e a produção do espaço, 2., 2013, Campo Mourão. Anais... Campo Mourão: UEP, 2013. p. 1-30.

CARMO, R. L.; ANAZAWA, T. M.; JOHANSEN, I. C. Seca nas metrópoles: materialização de um desastre anunciado. Waterlat-Gobacit Network Working Papers - Thematic Area Series SATAD TA8 - Water-related Disasters, v. 1, 2014, p. 91-109.

CENTRO DE PREVISÃO DO TEMPO E ESTUDOS CLIMÁTICOS. Síntese sinótica do mês de fevereiro de 2014. Cachoeira Paulista, 2014. Disponível em:<http://www.cptec.inpe.br/noticias/noticia/125973>. Acesso em: 17 jan. 2017.

CLIMANÁLISE. Cachoeira Paulista, v. 28, n.10, out. 2013a.

. Cachoeira Paulista, v. 28, n.11, nov. $2013 b$.

. Cachoeira Paulista, v. 28, n.12, dez. 2013c.

. Cachoeira Paulista, v. 29, n. 1, jan. 2014a.

. Cachoeira Paulista, v. 29, n. 2, fev. 2014b.

. Cachoeira Paulista, v. 29, n. 3, mar. 2014c.

MARENGO, J. A.; NOBRE, C. A.; SELUCHI, M. E.; CUARTAS, A.; ALVES, L. M.; MENDIONDO, E. M.; OBREGÓN, G.; SAMPAIO, G. A seca e a crise hídrica de 2014-2015 em São Paulo.

Revista USP, São Paulo. n. 106, p. 31-44, 2015.

MONTEIRO, C. A. de F. A. Frente polar atlântica e as chuvas de inverno na fachada suloriental do Brasil (contribuição metodológica à análise rítmica dos tipos de tempo no Brasil). São Paulo: IGEO/USP, 1969.

Análise rítmica em climatologia: problemas da atualidade climática em São Paulo e achegas para um programa de trabalho. São Paulo: USP, 1971.

Dinâmica Climática e as chuvas no Estado de São Paulo. Estudo geográfico sob forma de atlas. São Paulo: Universidade de São Paulo/Instituto de Geografia, 1973.

. O Clima e a organização do espaço no Estado de São Paulo: problemas e perspectivas.

São Paulo, Série Teses e Monografias, 28, USP/IGEOG, 1976.

Clima e Excepcionalidade: conjunturas sobre o desempenho da atmosfera como fenômeno climático. Florianópolis: UFSC, 233p. 1991.

NIMER, E. Climatologia do Brasil. IBGE, Rio de Janeiro, 422p, 1979.

Climatologia da Região Sudeste do Brasil - Introdução à Climatologia Dinâmica.

Revista Brasileira de Geografia, Rio de Janeiro, n.1, p.3-191, jan./mar. 1972.

PEIXOTO, J. P.: As Variações do clima e o ambiente - o homem, o clima e o ambiente II. Lisboa: Secretaria de Estado do Ambiente e dos Recursos Naturais, 1987.

QUADROS, M. F. L.; DIAS, M. A. F. S.; HERDIES, D. L.; GONÇALVES, L. G. G. Análise climatológica da precipitação e do transporte de umidade na região da ZCAS através da nova 
geração de reanálises. Revista Brasileira de Meteorologia, v.27, p.152-162, 2012. https://doi.org/10.1590/S0102-77862012000200004

REIBOTA, M. S.; GAN, M. A.; ROCHA, R. P.; AMBRIZZI, T. Regimes de precipitação na América do Sul: uma revisão bibliográfica. Revista Brasileira de Meteorologia, v. 25, n. 2, p. 185 - 204, 2010. https://doi.org/10.1590/S0102-77862010000200004

RIBEIRO, A. G. As Escalas do clima. Boletim de Geografia Teorética, Rio Claro, v. 23, p. 288 294, 1993.

VAREJÃO-SILVA, M. A. Meteorologia e climatologia. Brasília: INMET; Stilo, 2000.

Recebido em: 17/08/2017

Aceito para publicação em: 22/10/2018 